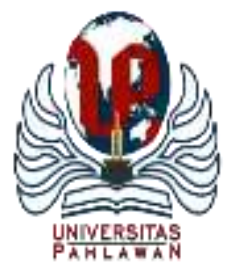

\title{
JURNALBASICEDU
}

Volume 5 Nomor 6 Tahun 2021 Halaman 5258 - 5265

Research \&Learningin Elementary Education

https://jbasic.org/index.php/basicedu

\section{Peran Pembelajaran Pkn SD dalam Membentuk Karakter Moral Siswa untuk Mempersiapkan Masa Depan Bangsa}

\author{
Dinie Anggraeni Dewi ${ }^{1 凶}$, Noviani Arum Sari Nur Hidayat², Ratih Novi Septian ${ }^{3}$, Silviana Lilis \\ Apriliani $^{4}$, Yayang Furi Purnamasari ${ }^{5}$ \\ Pendidikan Guru Sekolah Dasar, Universitas Pendidikan Indonesia, Indonesia ${ }^{1,2,3,4,5}$ \\ E-mail: dinieanggraenidewi@upi.edu ${ }^{1}, \underline{04 n o v i a n i a r u m s a r i @ u p i . e d u^{2}}$
}

\begin{abstract}
Abstrak
Dalam era modernisasi saat ini, bangsa Indonesia perlahan tapi pasti mengalami kriris karakter bangsa, di mana krisis ini didominasi oleh generasi muda, yang akan menjadi masa depan bangsa. Penelitian ini ditujukan untuk mengetahui peran dari pembelajaran PKn pada tingkatan SD dalam membentuk karakter moral siswa dalam mempersiapkan masa depan bangsa. Penelitan ini berbasis kualitatif yatu dengan studi literatur atau kajian pustaka dari berbagai buku dan artikel berkaitan dengan materi yang hendak dibahas. Studi literatur dalam penelitian ini dilakukan penulis melalui proses membaca, menyimpulkan, kemudian memproses dan mengembangkan data yang didapatkan sebagai bahan dari penelitian yang dilakukan. PKn sangat esensial dalam pembentukan karakter bangsa. PKn mengedukasi warga negara menjadi good citizen dan smart citizen untuk bersaing pada perkembangan dunia dalam era kompetitif untuk menyelesaikan permasalahan-permasalahan sosial pada kehidupan berbangsa dan bernegara. PKn memiliki tujuan untuk mengembangkan karakter warga negara yang berkesesuaian dengan nilainilai yang ada dalam Pancasila, karena sejatinya tujuan dari PKn sendiri adalah mengembangkan peserta didik menjadi generasi muda yang berakhlak mulia, menjadi warga negara yang aktif dalam mengungkapkan aspirasinya dan memiliki karakter yang sejalan dengan nilai-nilai Pancasila.
\end{abstract}

Kata Kunci: pembelajaran PKn, karakter moral, generasi muda.

\begin{abstract}
In the current era of modernization, the Indonesian nation is slowly but surely experiencing a crisis of national character, where this crisis is dominated by the younger generation, who will become the nation's future. This study aims to determine the role of Civics learning at the elementary level in shaping the moral character of students in preparing for the nation's future. This research is based on qualitative, namely literature study or literature review from various books and articles related to the material to be discussed. The literature study in this study was carried out by the author through the process of reading, concluding, then processing and developing the data obtained as material from the research conducted. Civics is very essential in the formation of national character. Civics educates citizens to become good citizens and smart citizens to compete in world developments in a competitive era to solve social problems in the life of the nation and state. Civics has the aim of developing the character of citizens per the values contained in Pancasila because the true purpose of Civics itself is to develop students into young people who have a noble character, become active citizens in expressing their aspirations, and have characters that are in line with Pancasila values.
\end{abstract}

Keywords: Citizen learning, High moral character, the young generation

Copyright (c) 2021 DinieAnggraeni Dewi, Noviani Arum SariNur Hidayat, Ratih Novi Septian, SilvianaLilis Apriliani, YayangFuri Purnamasari

$\triangle$ Corresponding author :

Email : dinieanggraenidewi@upi.edu

DOI : https://doi.org/10.31004/basicedu.v5i6.1621 


\section{PENDAHULUAN}

Di dalam lingkungan sosial, moral kini menjadi acuan di mana seseorang dinilai baik atau buruk oleh masyarakat. Dengan kata lain moral adalah nilai valid pada sebuah lingkup sosial yang menjadi tolak ukur setiap individu. Setiap manusia memiliki haknya masing-masing untuk mengukur baik atau buruknya moral manusia lain berdasarkan perilakunya dengan tetap didasari dengan aturan-aturan atau norma yang ada (Syamsul et al., 2017). Seperti yang kita ketahui, di Indonesia sering terjadi kasus pencurian, pembunuhan, pelecehan seksual, bullying, pencemaran nama baik, narkoba, penipuan, tawuran dan lainnya yang mana pelakunya tidak sedikit dari generasi muda yang nantinya akan menjadi penerus bangsa. Hal-hal itu terjadi karena bangsa ini telah mengalami krisis moral, di mana itu berdampak secara langsung kepada perkembangan dan perilaku anak. Moral sangat penting dimiliki oleh individu, karena moral adalah seperangkat nilai yang mana di dalamnya terdapat tuntunan, norma, patokan baik buruknya perilaku individu atau kelompok, kaidah kehidupan, serta adat istiadat (Bomans Wadu et al., n.d.). Namun, dalam kenyataannya perkembangan moral anak-anak di Indonesia saat ini semakin menurun dan memprihatinkan. Mulai dari anakanak kalangan bawah maupun anak-anak kalangan atas mereka bersikap acuh, kurang berpartisipasi dan bahkan tidak peduli terhadap keutuhan dan masa depan bangsa.

Generasi muda sebagai Agent of Change, sosok yang nantinya akan menjadi penerus bangsa harus mempunyai rasa tanggung jawab yang penuh terhadap negerinya. Unsur penting yang harus ada dalam generasi muda yaitu moralitas yang tinggi. UU NO. 20 Tahun 2003 Bab II Pasal 3 Undang-Undang Sisdiknas menerangkan bahwa pendidikan nasional memiliki banyak tujuan salah satunya membentuk individu-individu yang memliki moral dan berbudi pekerti luhur. Dalam sistem pendidikan nasional, Pendidikan Kewarganegaraan merupakan bagian utuh. Oleh karena itu, Pendidikan Kewarganegaraan dicantumkan dalam kurikulum sejak jenjang sekolah dasar.

Di jenjang pendidikan sekolah dasar, pembelajaran Pendidikan Kewarganegaraan menjadi pondasi atau dasar bagi anak untuk membentuk karakter generasi bangsa yang baik. Menurut Thomas Lickona yang dikutip oleh (Julaiha, 2014), karakter merupakan sifat alami yang ditunjukkan seseorang dalam memberikan respons atau tanggapan terhadap situasi yang dihadapinya secara bermoral. Sedangkan moral sendiri merupakan suatu tuntutan berkelakuan dengan baik yang dipunyai seseorang sebagai moralitas, yang terefleksikan pada cara berfikir, bersikap, dan dalam tingkah laku (Ananda, 2017). Ketika anak diberi pembelajaran tentang Pendidikan Kewarganegaraan ini, diharapkan anak-anak yang akan menjadi penerus bangsa dapat memiliki moral yang baik dan merubah moral yang buruk berdasarkan kesadaran dan keinginannya sendiri (Sekolah Dasar, n.d.) Akan tetapi, pada kenyataannya Pendidikan Kewargaegaraan belum mampu berperan untuk mewujudkan hal itu. Meskipun ada mata pelajaran Pendidikan Kewarganegaraan di sekolah, peserta didik kurang memahami untuk apa mata pelajaran itu ada. Sehingga, tidak adanya perubahan yang berarti atas tindakan atau karakter mereka yang tidak baik itu.

Dewasa ini, penelitian serupa mengenai peran PKn sebagai pembentukan karakter telah banyak dilakukan. Seperti hal nya pada penelitian (Bego et al., 2016), yang membahas mengenai peran guru pendidikan kewarganegaraan dalam membentuk karakter siswa dan implikasinya terhadap ketahanan siswa. Penelitian ini bermanfaat bagi calon pendidik, karena dengan ini para calon pendidik mengetahui pentingnya peran seorang guru dalam membangun karakter siswa melalui pembelajaran pendidikan kewarganegaraan. Berbeda dengan penelitian yang terdahulu, penelitian ini difokuskan pada peran pembelajaran PKn SD dalam membentuk karakter moral siswa untuk mempersiapkan masa depan bangsa. Berdasarkan hal tersebut, rumusan masalah dalam penelitian ini adalah bagaimana peran pembelajaran PKn SD dalam membentuk karakter moral siswa yang baik untuk mempersiapkan masa depan bangsa. Penelitian ini dilakukan dengan tujuan untuk mengedukasi apa peran pembelajaran PKn untuk membentuk karakter dan moral siswa yang sebenarnya. 
DOI : https://doi.org/10.31004/basicedu.v5i6.1621

\section{METODE PENELITIAN}

Dalam melakukan penelitian ini, penulis menerapkan metode penelitian studi literatur secara kualitatif atau deskriptif yang diperoleh melalui proses literasi dari berbagai buku, artikel, serta jurnal berkaitan dengan materi yang hendak dibahas. Penelitian kualitatif didapatkan melalui data yang dihimpun, dan bukan melalui angka. Sejalan dengan hal itu, penulis menilai bahwa penelitian yang dilakukan berdasarkan penelitian kualitatif dirasa lebih efektif untuk diterapkan dalam penelitian ini karena lebih menekankan pada prosedur ketimbang pada hasilnya saja. Sumber-sumber dalam penelitian ini di dapatkan dari data yang relevan dengan menekankan pada pengutipan artikel serta jurnal terakreditasi yang dipublikasikan maksimal sepuluh tahun terakhir. Dalam penelitian ini penulis berperan sebagai human instrument, peneliti yang mencari sumber relevan kemudian menganalisis sumber sendiri sehingga menjadi satu kesatuan yang sistematis. Studi literatur dalam penelitian ini dilakukan penulis melalui proses membaca, menyimpulkan, kemudian memproses dan mengembangkan data yang didapatkan sebagai bahan dari penelitian yang dilakukan.

\section{HASIL DAN PEMBAHASAN}

\section{Faktor Penyebab Menurunnya Moral Generasi Muda}

Saat ini anak sering memperlihatkan gambaran umum tentang perubahan dan pola kehidupan yang terjadi. Anak-anak tanpa ragu melakukan perbuatan dan perilaku yang tidak terpuji atau tidak sesuai dengan moral yang berlaku di sekitarnya. Akan tetapi, dibalik kurang baiknya moral anak pasti terdapat faktor atau penyebab sehingga anak dapat melakukan perbuatan yang menyimpang. Seperti anak yang sedang mengalami suatu masalah dan tidak mengerti bagaimana menyelesaikan permasalahannya, lembaga sosial yang kurang memberikan peran, dan hak-hak anak yang masih belum terpenuhi, hal-hal seperti itu bisa saja menjadi penyebab merosotnya moral dan karakter generasi muda (Yudia Fauzi et al., n.d.).

Perilaku anak di zaman ini dilihat dari aspek moral, norma/nilai, dan karakternya mulai terkikis, disertai dengan indikasi kemerosotan moral yang semakin jelas di era globalisasi ini. Hal-hal yang tidak sejalan dengan aturan dan juga norma banyak dilakukan oleh generasi muda bangsa ini. Pada umumnya, semua ini baik secara langsung maupun tidak langsung dipengaruhi oleh lingkungan sekitarnya. Lingkungan menjadi salah satu penyebab lain dari merosotnya moral dan karakter anak. Karakter yang baik di dapat dari lingkungan dan hasil belajar yang baik, begitupun sebaliknya. Seperti yang dikatakan oleh Prof. Hamdanah (MENGENAL PSIKOLOGI DAN FASE-FASE PERKEMBANGAN MANUSIA, n.d.), bahwa teman yang buruk pasti akan mempengaruhi sikap menyimpang pada seseorang. Hal ini sejalan dengan pendapat (PENDIDIKAN KARAKTER DALAM KURIKULUM 2013 Oleh: Sri Haryati (FKIP-UTM), n.d.) yang mengungkapkan bahwa karakter adalah upaya penerapan nilai, norma, kebiasaan serta perilaku yang diaktuakisasikan dalam aksi yang cenderung stabil dalam relasinya dengan lingkungan.

Anak-anak yang masih diusia sekolah dasar, yang notabenenya masih meniru apa yang terjadi disekitarnya, akan mudah terpengaruh oleh perilaku-perilaku yang tidak sesuai norma dan moral yang berlaku disekitarnya. Ketika anak melakukan perbuatan yang di luar kendali atau bertentangan pada norma yang berlaku di masyarakat itulah yang disebut dengan penyimpangan perilaku. Disini lah peran lembaga sosial yaitu sebagai sistem yang mengawasi bagaimana masyarakat bersikap dan bertingkah laku demi menjaga keamanan, keutuhan dan kestabilan masyarakat.

Selanjutnya, ada gadget dan media sosial yang saat ini mencuri perhatian mulai dari kalangan anakanak sampai orang tua, yang akhirnya menjadikan hampir semua orang memiliki media sosial. Media sosial tidak akan menjadi masalah ketika seseorang yang menggunakan secara baik dan bijak. Namun, media sosial akan menjadi masalah ketika banyak pengguna yang menyalah gunakannya. Sering kali muncul kontenkonten yang tidak seharusnya di posting, dan mudah diakses oleh siapa saja termasuk anak di bawah umur. 
Hal ini berakibat, banyak anak-anak yang nantinya akan melihat dan mengakses konten atau situs yang tidak sesuai itu dan mempengaruhi baik dari segi karakter dan tingkah laku anak. Anak-anak yang pemikirannya belum matang, akan mencerna secara mentah apa yang dilihat di media sosial kemudian mencontohnya. Hal tersebut yang perlahan-lahan mengikis moral dan karakter generasi muda (Rusnali, 2020).

Kemudian ada globalisasi yang menyebabkan moral dan karakter generasi muda menurun. Lajunya perkembangan globalisasi yang berdampak pada moral generasi muda. Mereka cenderung memilih kebudayaan yang berasal dari luar dibandingkan kebudayaannya sendiri, contohnya seperti para pemuda saat ini lebih memilih untuk mengenakan pakain minim dan sobek-sobek supaya terlihat kekinian yang di mana itu merupakan budaya barat, dari pada mengenakan batik atau baju yang sopan sebagai cerminan budaya bangsa Indonesia (Lestari et al., 2019). Selain pakaian, kini generasi muda juga sudah mulai meniru paham liberalisme yang dianut oleh negara bagian barat. Seperti mulai timbul perilaku individualisme yang hanya mementingkan dan memikirkan dirinya sendiri dan tidak mencermati sekelilingnya serta sikap peduli tidak peduli terhadap pemerintahan.

Faktor selanjutnya, yaitu menurunnya rasa cinta terhadap produk dalam negeri. Ini dikarenakan semakin banyaknya impor dari luar negeri yang berupa produk-produk seperti makanan, pakaian, dan lainnya yang menginvasi dunia pasar di Indonesia. Mereka mengandaikan bahwasanya jika memakai produk dalam negeri mereka akan terlihat lebih kuno, jadul dan kurang berkualitas. Padahal produk dalam negeri tingkat kualitasnya pun mampu bersaing dengan produk luar negeri (Hendayani, 2019).

Faktor lainnya yaitu adanya budaya hedonisme. Generasi muda di masa sekarang ini mempunyai tongkat obsesi yang besar terdahap dunianya. Segala hal yang berbau keduniaan dan sifatnya kekinian sehingga menjadi trend dimana-mana membuat generasi muda dengan mudah mengetahui alat-alat kontrasepsi, narkoba atau obat-obatan yang berbahaya dan terlarang yang dengan itu mengundang mereka untuk melakukan hal-hal yang menyimpang yang membuat moral dan karakternya menurun (Khanif et al., 2021).

\section{Ruang Lingkup dari Pembelajaran PKn di SD}

Sebelum menilik lebih lanjut mengenai ruang lingkup pembelajaran Pendidikan Kewarganegaraan di Sekolah Dasar, beberapa tujuan dari adanya PKn di Sekolah Dasar, menurut (Kurniawan, 2013) diantaranya:

- Dapat berpikir secara kritis, kreatif, dan rasional dalam menanggapi isu-isu kewarganegaraan.

- Berpartisipasi aktif, bertanggung jawab, dan tegas serta anti korupsi.dalam mengikuti kegiatan bermasyarakat, berbangsa, bernegara.

- Berkembang secara positif juga demokratis dengan membentuk pribadi berdasarkan karakter-karakter dari masyarakat Indonesia, supaya dapat hidup berdampingan dengan bangsa-bangsa lain.

- Dengan memanfaatkan teknologi informasi dan komunikasi, dapat berinteraksi dengan bangsa-bangsa lain dalam peraturan dunia, baik secara langsung atau pun tidak langsung.

Secara garis besar, materi Pendidikan Pancasila dan Kewarganegaraan (PPKn) di sekolah dasar mencakup konsep nilai, norma, dan moral (Azizah et al., 2020). Konsep yang dimaksud disini adalah PKn diharapkan dapat mengajarkan siswa untuk berpikir secara runtut dan kronologis. Untuk nilai, maksudnya adalah kualitas kebaikan yang harus diaktualisasikan secara terus menerus. Sedangkan norma adalah aturan yang ada atau lahir dimasyarakat dan moral adalah aktualisasi dari nilai.

PKn memiliki ruang lingkup yang luas untuk diajarkan, terutama pada jenjang sekolah dasar. Seperti yang diungkapkan (Kurniawan, 2013), bahwa salah satu program pendidikan atau mata pelajaran yang ruang lingkupnya cukup luas dan mempunyai sedikitnya tiga hal atau domain dalam proses pembangunan karakter, yaitu mata pelajaran Pendidikan Kewarganegaraan atau PKn. Tiga hal atau domain itu, seperti (1) jika ditinjau dari sudut pandang konseptual, yang memiliki peran dalam mengembangkan konsep-konsep dan teori yaitu 
Pendidikan Kewarganegaraan, (2) jika ditinjau secara kurikuler, untuk mempersiapkan anak-anak menjadi manusia dewasa yang berkarakter melalui berbagai lembaga pendidikan, sejumlah program pendidikan dan model implementasinya dikembangkan oleh Pendidikan Kewarganegaraan, dan (3) secara sosial kultural, agar menjadi warga negara yang baik, proses pembelajaran kepada masyarakat dilaksanakan oleh Pendidikan Kewarganegaraan. Ruang lingkup yang paling menonjol adalah mengenai wawasan kebangsaan dan Pendidikan karakter. (Sekolah Dasar, n.d.) dalam bukunya yang berjudul 'Pembelajaran PKn di Sekolah Dasar' mengutarakan jika, guru harus memiliki pengetahuan dan pemahaman yang mumpuni, mengenai pendidikan karakter, seperti pengertian pendidikan karakter, nilai-nilai yang termasuk dalam pendidikan karakter, dan bagaimana pendidikan karakter dilaksanakan, dapat diaplikasikan pada mata pelajaran PKN di sekolah dasar.

(Sekolah Dasar, n.d.) juga menyebutkan bahwa ada kaitan erat antara ilmu sosial dan PKn, secara historis dan pembahasan materi di dalamnya, karena PKn ini membahas tentang negara dan masyarakat di dalamnya. Hal ini tentu dapat dibenarkan, karena kehidupan bernegara juga termasuk ke dalam kehidupan sosial. Salah satu contohnya adalah individu atau kelompok yang ada dalam suatu negara itu saling berinteraksi dan berkomunikasi satu sama lain, sehingga dapat mewujudkan persatuan dan kesatuan bangsa, serta kebhinnekaan.

Ruang lingkup PKn tidak hanya sebatas pendidikan karakter dan ilmu sosial saja, tetapi juga erat kaitannya dengan pendidikan agama. Indonesia memiliki setidaknya enam agama yang dianut oleh mayoritas penduduk Indonesia. Dalam setiap agama, tentu saja ada ajarannya sendiri. Beragamnya agama dan kepercayaan inilah yang menambah kekayaan bangsa Indonesia. Untuk itu, adanya PKn yang di dalamnya mengandung pembelajaran Pancasila ini, dapat menjadi pembelajaran sendiri bagi siswa, terutama sekolah dasar untuk saling menjaga keutuhan negara walaupun kepercayaan terhadap Tuhan mereka berbeda. (Sekolah Dasar, n.d.) juga menambahkan bahwa ada kesamaan antara PKn dan Pendidikan Agama ditinjau dari tujuannya, yaitu menegakkan aklhak atau budi pekerti yang luhur dan nilai-nilai kehidupan bermasyarakat juga bernegara.

\section{Peran Pembelajaran PKn di SD Kaitannya dengan Karakter dan Moral Generasi Muda}

PKn berfokus pada penanaman pemahaman terhadap konsep kenegaraan serta berisi hal-hal yang sering diterapkan dalam kehidupan sehari-hari. Yang selanjutnya, hal itu diharapkan dapat membentuk generasi yang mencintai serta melestarikan keutuhan dan persatuan bangsanya. Pemahaman dan peningkatan sikap serta tingkah laku yang bersumber pada nilai Pancasila dan juga budaya bangsa adalah sesuatu yang diutamakan pada pendidikan kewarganegaraan (Rahmatiani, n.d.).

Mata pelajaran Pkn dan pendidikan karakter memiliki kaitan yang erat satu sama lain. Nilai-nilai yang ada pada pendidikan karakter di Indonesia dirtikan melalui empat sumber, yaitu Pancasila, tujuan pendidikan nasional, agama, dan budaya (Nugroho et al., 2019). Secara programatik pembelajaran pendidikan kewarganegaraan menitik beratkan pada pembekalan pengetahuan politik, serta hukum yang diterapkan dalam masyarakat Indonesia. Bahan ajar secara jelas, berdasarkan teori, terkonsep, serta normatif mengandung berbagai nilai moral dan panduan serta cara penerapannya. Program Pkn berfokus pada pembentukan individu yang memiliki sifat demokratis, terampil, religius, mencintai bangsa dan negaranya, serta menjunjung tinggi nama baik dan martabat bangsa dalam proses pergaulan antar-bangsa yang sedang dan akan terus terjadi di dunia. Pembelajaran Pkn secara prosedural mengandung materi ajar yang secara fungsional membentuk, membina, dan mengembangkan potensi yang dimiliki oleh peserta didik baik dalam lingkungan fisik ataupun nonfisik secara humanis, demokratis, dan fungsional.

Menurut (Riadin \& Salahudin Permadi, 2019) PKn pada tingkat sekolah dasar dimaknai sebagai suatu rangkaian kegiatan belajar mengajar yang bertujuan untuk membantu siswa sehingga siswa tersebut mampu belajar dengan layak dan melahirkan manusia berjiwa nasionalis dalam penciptaan karakter bangsa yang 
berorientasi pada pembentukan masyarakat yang memposisikan demokrasi pada kehidupan berbangsa dan bernegara yang didasarkan pada Pancasila, UUD 1945 serta norma dan yang diterapkan di masyarakat. Menurut (Nugroho et al., 2019), PKn selaku mata pelajaran yang didasarkan pada pengembangan karakter merupakan jalan keluar dari permasalah dalam penanaman karakter bangsa.

Karakter bangsa termasuk dalam upaya kolektif sistematik yang dilaksanakan oleh suatu negara kebangsaan dalam rangka menciptakan kehidupan bangsa serta negaranya sejalan dengan konstitusi, dasar, ideologi, haluan negara, dan kecakapan kolektifnya pada konteks kehidupan regional, nasional, serta global yang beradab dan sesuai aturan. Hal-hal itu ditujukan agar terbentuk suatu bangsa yang kuat, berakhlak mulia, bertoleran, kompetitif, berkembang dinamis, berorientasi pada IPTEK, bermoral, bergotong royong, berbudi luhur, berjiwa patriotik, yang seluruhnya berdasar pada keimanan dan ketakwaan terhadap Tuhan Yang Maha Esa, berlandaskan Pancasila (Tuhuteru, n.d.).

PKn memegang urgensi dalam pembentukan moral generasi muda serta karakter bangsa. Oleh karena itu, pada pengaplikasiannya diperlukan pengenalan suatu materi pendidikan kewarganegaraan yang berkesinambungan dengan nilai-nilai karakter suatu bangsa. Agar kemajuan suatu bangsa dapat tercapai, terdapat karakter-karakter yang menjadi tolak ukur bagi pengembangan karakter pada generasi muda, yaitu: religius, kerja keras, jujur, semangat kebangsaan dan cinta tanah air, kreatif, peduli lingkungan dan sosial, toleransi, disiplin, tanggung jawab, serta demokratis (Izma et al., 2019).

Pada penerapannya, PKn meyalurkan konstribusi pada pembentukan dan penanaman moral bangsa lewat beberapa tahapan, yaitu:

1. Pembelajaran. Sesungguhnya kegiatan pembelajaran selain dilaksanakan untuk membentuk generasi muda yang memahami secara utuh kompetensi yang ditetapkan, juga diprogram untuk dapat menciptakan peserta didik yang memahami, memafhumi, dan mengahayati nilai-nilai lalu mengimplementasikannya sebagai perilaku.

2. Kegiatan ko-kurikuler dan ekstra kurikuler. Kegiatan ini harus didukung dengan tata cara pelaksanaan, pemberdayaan kapasitas SDM guna menunjang konkretisasi pendidikan 18 karakter serta menggiatkan kembali kegiatan ko-kurikuler dan juga ekstra-kurikuler yang telah ada menuju pada pengembangan karakter.

3. Alternatif pengembangan serta bimbingan karakter di sekolah sebagai pengaktualisasian budaya.

4. Kegiatan sehari-hari di rumah serta di masyarakat.

PKn sangat esensial dalam pembentukan karakter bangsa. PKn merupakan salah satu fondasi pada pembentukan karakter serta jati diri bangsa yang berarti PKn mengedukasi warga negara menjadi good citizen dan smart citizen untuk bersaing pada perkembangan dunia dalam era kompetitif untuk menyelesaikan permasalahan-permasalahan sosial pada kehidupan berbangsa dan bernegara. PKn memiliki tujuan untuk mengembangkan karakter warga negara yang berkesesuaian dengan nilai-nilai yang ada dalam Pancasila. PKn adalah salah satu cara yang tepat untuk menerapkan nilai-nilai karakter pada proses pembelajaran PKn kepada siswa, karena sejatinya tujuan dari PKn sendiri adalah mengembangkan peserta didik menjadi generasi muda yang berakhlak mulia, menjadi warga negara yang aktif dalam mengungkapkan aspirasinya dan memiliki karakter yang sejalan dengan nilai-nilai Pancasila.

Berdasarkan hasil studi literatur yang didapatkan dengan menelaah bahan kajian mengenai permasalahan ini, menegaskan bahwa Pkn berisi penanaman konsep kenegaraan yang berorientasi dalam pembentukan generasi yang mencintai serta melestarikan keutuhan dan persatuan bangsanya. Program Pkn berfokus pada pembentukan individu yang memiliki sifat demokratis, terampil, religius, berorientasi pada IPTEK, bermoral, mencintai dan menjaga nama baik bangsa dan negaranya serta mengembangkan potensi yang dimiliki peserta didik secara optimal. Hal ini sejalan dengan riset terdahulu yang menyatakan bahwa pembelajran PKn berperan penting dalam pembentukan karakter moral siswa. Pkn sebagai mata pelajaran merupakan jalan keluar terhadap problematika dalam penanaman karakter bangsa. Oleh karena itu, dalam 

Depan Bangsa - DinieAnggraeni Dewi, Noviani Arum SariNur Hidayat, Ratih Novi Septian, SilvianaLilis Apriliani, YayangFuri Purnamasari

DOI : https://doi.org/10.31004/basicedu.v5i6.1621

pengaplikasiannya diperlukan pengenalan suatu materi yang berkesinambungan dengan nilai-nilai karakter suatu bangsa.

\section{KESIMPULAN}

Maraknya fenomena kemerosotan karakter dan moral generasi muda bangsa tentu didasari oleh beberapa faktor atau penyebabnya. Salah satunya adalah pengaruh lingkungan sekitar. Pembelajaran Pkn terutama di SD, mengambil peran besar dalam menyikapi terkikisnya karakter dan moral dari generasi muda yang akan menjadi pemimpin bangsa di masa depan nanti, seperti mengadapi permasalahan-permasalahan sosial dalam berbangsa dan bernegara. Melalui pembelajaran yang menekankan pada nilai-nilai luhur Pancasila dan pendidikan karakter, serta berkaitan dengan ilmu sosial dan agama, maka diharapkan pembelajaran PKn yang diajarkan di sekolah dasar ini dapat memperbaiki karakter dan moral bangsa.

\section{UCAPAN TERIMA KASIH}

Tanpa adanya dukungan dan bimbingan dari dosen mata kuliah Pembelajaran PKn di SD, Dr. Dinie Anggraeni Dewi, M.Pd. dan Yayang Furi Purnamasari, S.Pd. M. Pd., penulis tidak akan dapat menyelesaikan tulisan ini dengan baik. Untuk itu, penulis mengucapkan banyak terima kasih kepada beliau atas arahan, bimbingan, dan dukungannya kepada penulis.

\section{DAFTAR PUSTAKA}

Ananda, R. (2017). Implementasi Nilai-Nilai Moral Dan Agama Pada Anak Usia Dini. Jurnal Obsesi : Jurnal Pendidikan Anak Usia Dini, 1(1), 19. Https://Doi.Org/10.31004/Obsesi.V1i1.28

Azizah, A. B., Nisrina Huwaida, A., Asihaningtyas, F., \& Fatharani, J. (2020). Konsep, Nilai, Moral Dan Norma Dalam Pembelajaran Ppkn Sd. In Jurnal Pendidikan Dan Ilmu Sosial (Vol. 2, Issue 1). Https://Ejournal.Stitpn.Ac.Id/Index.Php/Nusantara

Bego, K. C., Studi, P., Sejarah, P., \& Flores, U. (2016). Peran Guru Pendidikan Kewarganegaraan Dalam. 5(3), 235-240.

Bomans Wadu, L., Jaisa, Y., \& Kanjuruhan Malang, U. (N.D.). Pembinaan Moral Untuk Memantapkan Watak Kewarganegaraan Siswa Sekolah Dasar Kelas Tinggi (Vol. 2, Issue 2). Http://Ejournal.Unikama.Ac.Id/Index.Php/Jmk

Hendayani, M. (2019). Problematika Pengembangan Karakter Peserta Didik Di Era 4.0. Jurnal Penelitian Pendidikan Islam, 7(2), 183. Https://Doi.Org/10.36667/Jppi.V7i2.368

Izma, T., Yolanda Kesuma, V., Kunci, K., \& Dan Pendidikan Kewarganegaraan, N.-N. (2019). Peran Pendidikan Kewarganegaraan Dalam Membangun Karakter Bangsa (Vol. 17, Issue 1).

Julaiha, S. (2014). Implementasi Pendidikan Karakter Dalam Pembelajaran (Vol. 14, Issue 2).

Khanif, R., Muslimah, \& Ahmadi. (2021). Urgensi Pengelolaan Keluarga Sebagai Madrasatul'ula Dalam Meminimalisir Dekadensi Moral Generasi Muda Masa Kini. Jurnal Pendidikan Islam Al-Affan, 1(2), $103-112$.

Kurniawan, M. I. (2013). Integrasi Pendidikan Karakter Ke Dalam Pembelajaran Kewarganegaraan Di Sekolah Dasar. Jurnal Pemikiran Dan Pengembangan Sekolah Dasar (Jp2sd), 1(1), 37. Https://Doi.Org/10.22219/Jp2sd.V1i1.1528

Lestari, E. Y., Janah, M., \& Wardanai, P. K. (2019). Menumbuhkan Kesadaran Nasionalisme Generasi Muda Di Era Globalisasi Melalui Penerapan Nilai-Nilai Pancasila. Adil Indonesia Jurnal, 1(1), 20-27. 
Depan Bangsa - DinieAnggraeni Dewi, Noviani Arum SariNur Hidayat, Ratih Novi Septian, SilvianaLilis Apriliani, YayangFuri Purnamasari

DOI : https://doi.org/10.31004/basicedu.v5i6.1621

Mengenal Psikologi Dan Fase-Fase Perkembangan Manusia. (N.D.).

Nugroho, H. W., Suyahman, S., \& Suswandari, M. (2019). Peranan Mata Pelajaran Ppkn Dalam Rangka Menumbuhkan Nilai Karakter Religius Siswa Kelas Iv Di Sdn 3 Wuryorejo. Civics Education And Social Science Journal (Cessj), 1(1). Https://Doi.Org/10.32585/Cessj.V1i1.356

Pendidikan Karakter Dalam Kurikulum 2013 Oleh: Sri Haryati (Fkip-Utm). (N.D.).

Rahmatiani, L. (N.D.). Prosiding Seminar Nasional Kewarganegaraan Pendidikan Kewarganegaraan Sebagai Pembentuk Karakter Bangsa.

Riadin, A., \& Salahudin Permadi, A. (2019). 28) (Vol. 14, Issue 1).

Rusnali, A. N. U. R. A. (2020). Media Sosial Dan Dekadensi Moral Generasi. 1(1), 1-16.

Sekolah Dasar, D. (N.D.). Pembelajaran Pkn.

Syamsul, Y., Widodo, R., \& Tinus, A. (2017). Peranan Pendidikan Kewarganegaraan (Pkn) Dalam Pembentukan Moral Peserta Didik. Jurnal Civic Hukum, 2(1), 36. Https://Doi.Org/10.22219/Jch.V2i1.9902

Tuhuteru, L. (N.D.). Peran Pendidikan Kewarganegaraan Dalam Peningkatan Pembentukan Karakter Bangsa Di Tengah Arus Globalisasi.

Yudia Fauzi, F., Arianto, I., \& Solihatin, E. (N.D.). Peran Guru Pendidikan Pancasila Dan Kewarganegaraan Dalam Upaya Pembentukan Karakter Peserta Didik. Http://Skripsippknunj.Org 